Intl. J. River Basin Management Vol. 6, No. 3 (2008), pp. 213-223

(C) 2008 IAHR, INBO \& IAHS

\title{
A study of hydraulic characteristics for flow in equatorial rivers
}

\author{
LAI SAI HIN, Lecturer, River Engineering and Urban Drainage Research Centre (REDAC), Universiti Sains Malaysia, Engineering \\ Campus, 14300 Nibong Tebal, Penang, Malaysia. E-mail: redaclai@eng.usm.my
}

NABIL BESSAIH, Department of Civil Engineering, Faculty of Engineering, Universiti Malaysia Sarawak (UNIMAS), 94300 Kota Samarahan, Sarawak, Malaysia

LAW PUONG LING, Department of Civil Engineering, Faculty of Engineering, Universiti Malaysia Sarawak (UNIMAS), 94300 Kota Samarahan, Sarawak, Malaysia

AMINUDDIN AB. GHANI, Professor, Deputy Director, REDAC, Universiti Sains Malaysia, Engineering Campus, 14300 Nibong Tebal, Penang, Malaysia.E-mail: redac02@eng.usm.my

NOR AZAZI ZAKARIA, Professor, Director REDAC, Universiti Sains Malaysia, Engineering Campus, 14300 Nibong Tebal, Penang, Malaysia.E-mail: redac01@eng.usm.my

MAH YAU SENG, Department of Civil Engineering, Faculty of Engineering, Universiti Malaysia Sarawak (UNIMAS), 94300 Kota Samarahan, Sarawak, Malaysia

\begin{abstract}
This paper presents the results obtained from field measurements taken in several frequently flooded equitorial rivers, including velocity distributions, stage discharge relationships, roughness behaviours and discharge estimation. These have illustrated the large difference in velocity between the main channel and floodplain under flood conditions, and the effects of momentum transfer between deep and shallow flow, which include reduction in main channel velocity and discharge capacity, leading to a reduction in compound section capacity at depth above bankfull. Another significant characteristic that has been found is that the floodplain regions behave as storage reservoirs $(V=0 \mathrm{~m} / \mathrm{s})$ in most cases due to high resistance of long and thick grasses along the flood plains $(n=0.07-0.1)$. Flow resistance relationships have been presented in terms of Manning's coefficient and Darcy-Weisbach friction factor, showing the complex nature of flow resistance in the rivers and further explaining the danger inherent in the conventional practices of extrapolating inbank data for the analysis of overbank flows. Results for discharge estimation have been shown for comparison with actual data, the errors incurred by applying empirical methods to compound channel flows have been quantified and found to depend on the particular method used.
\end{abstract}

Keywords: Discharge estimation; flow resistance; equitorial river; overbank flow; velocity distribution.

\section{Introduction}

A large number of hydro-engineering problems are related to open flow in compound channels. An understanding of flow in compound channels or rivers with floodplains is essential in practical problems of flood mitigation and floodplain management. It is therefore important for flow simulation to be correct not only on the water surface elevation, but also the sectional discharge and velocity distribution, during the event of overbank flows. Unfortunately, most of the studies that have been carried out are based on idealized experimental laboratory investigations. Field study is rare, partly because compound channel flow conditions occur typically under flood conditions when acquisition of data is difficult and sometimes dangerous. In the work presented, an attempt was made to focus on rivers under flood conditions.

\section{Open channel flow resistance}

In open channel flow prediction, it is usually assumed that the flow is parallel and has a uniform velocity distribution (steady-uniform flow) and that the slope of the channel is small. Under such conditions, the convection acceleration is zero, and the streamlines are straight and parallel. Because of the velocity does not change, the velocity head will be constant; therefore, the energy grade line and water surface will have the same slope as the channel bottom.

Based on the above assumptions, a series of empirical methods of discharge estimation in open channels and rivers have been developed. The simplest of these are uniform flow equations attributed to Chezy and Manning, with parallel development in pipe flow leading to the Darcy-Weisbach equation. The uniform

Received on February 17, 2007. Accepted on October 31, 2007. 